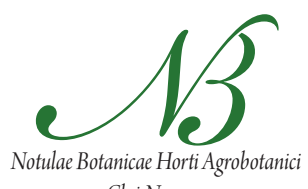

Cluj-Napoca

\title{
Does Epidermal Thickness Influence White Cabbage Resistance against Onion Thrips (Thrips tabaci)?
}

\author{
János BÁLINT'12, Natasa BURGHARDT'1, Mária HÖHN³, Béla PÉNZES', JózsefFAIL* \\ ${ }^{1}$ Department of Entomology, Faculty of Horticultural Science, Corvinus University of Budapest, Villanyi ut 29-43, Hungary; \\ jozseffail@uni-corvinus.hu (*correspondingauthor),bnati84@yahoo.com,bela.penzes@uni-corvinus.hu \\ ${ }^{2}$ Department of Horticulture, Faculty of Technical and Human Sciences, Sapientia University, \\ Sighişoara str.1/C, Tîrgu-Mures, Romania; balintjanos@ms.sapientia.ro \\ ${ }^{3}$ Department of Botany, Faculty of Horticultural Science, Corvinus University of Budapest, \\ Villányi üt 29-43, Hungary; maria.hohn@uni-corvinus.bu
}

\begin{abstract}
Present studies were made to investigate the association between epidermal thickness and resistance of white cabbage against onion thrips, Thrips tabaci Lindeman, 1889 (Thysanoptera: Thripidae). Six white cabbage varieties including three susceptible ('Green Gem', 'Hurricane' and 'Quisor') and three resistant to onion thrips ('Balashi', 'Bloktor' and 'Riana') were involved in the studies. Additionally, the extent of antixenotic resistance during head formation and the level of thrips damage at harvest were also assessed and compared between varieties. A higher density of onion thrips was observed on susceptible than on resistant varieties. The results indicate that the epidermis is of the same thickness in susceptible white cabbage varieties as in resistant ones; therefore, we conclude that the thicknesses of either the adaxial or the abaxial part of the epidermis of head-forming leaves is not responsible for cabbage resistance to thrips. The study thus confirms that antixenotic resistance of white cabbage to thrips is not determined by epidermal thickness.
\end{abstract}

Keywords: antixenosis, epidermis, feeding behaviour, resistant varieties

\section{Introduction}

White cabbage belongs to the oldest group of cultivated vegetable plants in the Middle East and Europe and its field cultivation has been known for more than 500 years (Zatykó, 2004). Currently, it represents about $10 \%$ of the world's vegetable production and $20 \%$ of the total cultivation area in Europe (Zatykó, 2004). Onion thrips (Thrips tabaci Lindeman, 1889) is one of the most important pests of cabbage. Thrips damage to white cabbage was reported for the first time in USA in the late nineteenth century (Lintner, 1892). In 1894, J. W. Cain reported a bronze discolouration on the surface of white cabbage head-forming leaves for the first time, which was attributed to damage by onion thrips (Sirrine and Lowe, 1894). In the last two decades, this pest has become a major problem in the summer production period (Fail et al., 2002).

One of the first descriptions of thrips damage in general reported that they pierce plant tissues and suck out the cell contents, causing cell walls to collapse (Horton, 1918, Scirtothrips citri Moulton). Subsequently, the feeding behaviour of numerous thrips was observed on leaves. One of the most-studied species is onion thrips, which uses the tip of its mouthcone to enlarge the feeding hole, facilitating penetration through even a thick wax layer barrier and allowing easier stylet removal after feeding. The wax layer impedes the feeding progress and thrips have to push deeper for the mandible to reach underlying leaf cells. During this process, thrips probably perceive information concerning the physical and chemical characteristics of the leaves (Chisholm and Lewis, 1984). Several studies performed in cultivated plants other than white cabbage, however, have revealed correlations between epidermal thickness and the intensity of thrips damage on leaves ( Naik et al., 2000; Zeier and Wright, 1995).

The physical characteristics of leaves, such as the presence of trichomes, leaf surface wax and the thickness of the epidermal cell wall can cause antixenotic resistance against thrips (Painter, 1951; Wardle and Simpson, 1927; Zeier and Wright, 1995).

The feeding behaviour of adult and nymph black vine thrips (Retithrips syriacus - Mayet, 1890) on castor oil plants is more likely to be influenced by the number of stoma on leaves than the epidermal thickness (Ananthakrishnan, 1955). Studies that have examined cross-sections of gladiolus leaves have reported a negative correlation between thrips damage that causes bulging spots on leaves and the presence of wax on leaves (Zeier and Wright, 1995). The feeding of adult western flower thrips (Frakliniella occidentalis Pergande) has been observed on several tomato species and only the epidermal cells of species that showed a strong antixenotic resistance were damaged. Other plants lacking antixenotic resistance suffered severe damage to palisade parenchyma and spongy parenchyma 
cells (Kumar et al., 1995). Later studies carried out with mulberry thrips (Pseudodendrothrips mori, Niwa 1908) on different mulberry varieties confirmed that the thickness of the adaxial part of the epidermis from the most resistant to the most susceptible varieties, varied between 30.67 and $24.27 \mu \mathrm{m}$, whereas that of the lower epidermis varied between 11.58 and $8.97 \mu \mathrm{m}$. A strong correlation was also found between epidermal thickness and resistance by Naik et al. (2000).

Wardle and Simpson (1927) and Abdel-Gawaad et al. (1973) suggested that differences in resistance to onion thrips in cotton might be caused by epidermal thickness. A typical cotton leaf cross-section measured $143 \mu \mathrm{m}$, the adaxial part of epidermis $17 \mu \mathrm{m}$, the palisade tissue $54 \mu \mathrm{m}$, the mesophyll layers $61 \mu \mathrm{m}$, and the lower epidermis 11 $\mu \mathrm{m}$. Thrips make a slit in an epidermal cell by using the mandible, but cannot pierce the opposite wall. This wall and some of the underlying mesophyll cells are reached by the longer and more slender maxilla, which can also pierce these cells. The contents of these cells are sucked by onion thrips using its pharyngeal pump, with air partly filling the space left.

Onion thrips probably prefer the lower epidermis of cotton seedling leaves, as demonstrated by small round spots produced on this part of the plant (Painter, 1951). However, other plant characteristics than epidermal thickness might play a role in the resistance of cotton to onion thrips, since the lower epidermis of the thrips-resistant cotton variety, 'Giza 31' was as thin $(6.6 \mu \mathrm{m})$ as that of two susceptible varieties, 'Giza 68' and 'Menoufi' (AbdelGawaad et al., 1973).

No previous studies have analysed the relationship between epidermal thickness of different white cabbage varieties and resistance to onion thrips. Therefore, the main aim of this study was to address this and to reveal whether the epidermal thickness of the studied white cabbage varieties is correlated with the host selection of and consequently with the level of damage caused by onion thrips.

\section{Materials and methods}

\section{Sampling method and field location}

Six white cabbage varieties were studied in two consecutive years. Three of these varieties ('Green Gem,' 'Hurricane' and 'Quisor') were considered susceptible, whereas the other three ('Balashi', 'Bloktor' and 'Riana') were considered resistant to thrips. Previous experiment made by Fail et al. $(2005,2006,2008)$ clearly define the resistance and susceptibility of these six white cabbage varieties. Plants were raised at the Tordas Station of the Central Agricultural Office, Tordas, Hungary. Seedlings were planted on 15th of May in the first year and $11^{\text {th }}$ of June in the second year, $60 \mathrm{~cm}$ apart. Head formation started in June and July (Tab. 1). In the first year, two blocks for each variety were established in a randomised block design, each with six rows and 13 plants in each row. In the second year, plots were established as in the previous year but loss of seedlings allowed for only five rows in the plots of 'Balashi' and 'Bloktor'. Samples were collected two times in each consecutive year. At each sampling event, 48 plants were collected for every variety.

\section{Antixenotic evaluation}

Antixenotic resistance (AR) was considered as the number of colonising thrips at the beginning of the vegetation period during cabbage head formation. To estimate the AR of the varieties, the number of colonising adult thrips was assessed at the beginning of cabbage head formation in the first year and a similar assessment was carried out in the second year. Samples consisted of 24 randomly selected cabbage heads from blocks of each variety, resulting in 288 cabbage heads at each sampling time. Cabbage heads were kept in plastic bags for approximately two hours at room temperature in the laboratory until the AR evaluation was performed. During the evaluation, the first ten outer head leaves from one cabbage were removed one by one and the number of adult thrips on both adaxial and abaxial sides of the epidermis was counted under a stereomicroscope. Resistance can be considered as a relative feature and is not reflected by an absolute number of thrips, therefore, the proportion of total abundance (PTA) was calculated separately for each variety, as a total of all individuals from the first sample. The calculation was repeated for the other sets of samples and these values were considered as variables in statistical analyses

\section{Onion thrips damage assessment}

Damage assessment was carried out at harvest maturity of the varieties in two consecutive years. Similar to the antixenotic evaluation, 48 randomly selected cabbage heads were collected from each variety in both years. To estimate thrips damage, an evaluation method was applied (Fail, 2006). Cabbage head leaves were evaluated and peeled off one by one until no damage was found on four consecutive leaves. During this procedure, the extent of damage was assessed for each examined head-forming leaf, as the proportion of damaged surface to the entire surface of the leaf. A scale from zero to one with an accuracy of 0.1 was used, where zero represented no damage and one indicated $100 \%$ damage. The cumulative value of damage ratios estimated for each examined leaf in one cabbage head was used in the subsequent statistical analysis. The total number of damaged leaves in a given cabbage head was also considered in data analysis.

\section{Epidermal thickness evaluation}

Samples were collected from the second head-forming leaf at both sampling times in the first year and only once at the first sampling in the second year. The number of replicates for each sampling event was 48 for each variety. Plant tissue sections were prepared immediately after determining the number of adult thrips and the extent 
446

of damage in the first year, however, in the second year, samples were stored in a refrigerator at $4^{\circ} \mathrm{C}$ before preparation. Tissue sections from the second head-forming leaves were prepared, to determine the epidermal thickness, using freezing microtomes. Three samples of $5 \times 5 \mathrm{~mm}$ leaf piece were excised from the leaves. This contained a main or a secondary leaf vein and enabled the separation of the adaxial and abaxial leaf parts. Three sections were prepared from each leaf and were mounted in Berlese solution on slides. The single cell-layered epidermis in white cabbage consists of tabular-shaped cells with a slightly convex surface. To measure the epidermal thickness on leaf crosssections, the adaxial and abaxial leaf parts were first identified by locating the vascular bundle and the primary or secondary veins. A stoma was then located on both adaxial and abaxial leaf surfaces under the microscope, and two epidermal cells were selected, each flanking a particular stoma. Because stomata are surrounded by subsidiary cells, the width of the epidermal cells adjacent to the additional cells was measured on both sides using an ocular micrometer. This procedure was repeated for the other two leaf cross-sections of a given sample and yielded six measurements for the adaxial epidermis and six for the abaxial epidermis for each sample. Statistical analyses were performed on the mean of these six individual measurements.

\section{Data Analyses}

Data were analysed with PASW Statistics 18, release 18.0.0 (30 August, 2010). The original data met the assumptions of normality (using the Kolmogorov-Smirnov test), therefore, epidermal thickness between varieties was compared using Tukey's HSD test or the Games-Howell test, depending on the homogeneity of the variance (assessed using the Levene test). For the antixenotic evaluation and damage assessments, normality was not met, therefore, the nonparametric Kruskal-Wallis test was used, followed by Mann-Whitney $U$ tests to compare varieties. All data are reported as means with $95 \%$ confidence intervals. Means with different letters in tables represent statistically significant differences.

For testing the block effects of the PTA, total damaged leaf surface and the number of damaged leaves, a general linear model was computed using $\mathrm{R}$ language and environment. The model residuals were additionally tested for normality and homogeneity of variance and according to these results, the package "geepack" geeglm function (Fit Generalised Estimating Equations - GEE) was used (Højsgaard et al., 2006; R Core Team, 2012; Yan and Højsgaard, 2012). A similar general linear model was computed, to test the block effects of epidermal thickness variation using the glm function (R Core Team, 2012).

Tab. 1. Start of head formation and timetable of evaluations

\begin{tabular}{|c|c|c|c|c|c|c|}
\hline \multirow[b]{2}{*}{ Variety } & \multicolumn{2}{|c|}{ Cupping starts } & \multicolumn{2}{|c|}{ Antixenotic evaluation } & \multicolumn{2}{|c|}{ Damage assessment } \\
\hline & date & d.a.t. ${ }^{*}$ & date & d.a.t. ${ }^{*}$ & date & d.a.t. ${ }^{*}$ \\
\hline & \multicolumn{6}{|c|}{ First year } \\
\hline 'Balashi' & $10^{\text {th }}$ of June & 26 & $25^{\text {th }}$ of June & 41 & $11^{\text {th }}$ of August & 88 \\
\hline 'Bloktor' & $18^{\text {th }}$ of June & 34 & $25^{\text {th }}$ of June & 41 & $10^{\text {th }}$ of October & 148 \\
\hline 'Green Gem’ & $10^{\text {th }}$ of June & 26 & $19^{\text {th }}$ of June & 35 & $12^{\text {th }}$ of August & 89 \\
\hline 'Hurricane' & $13^{\text {th }}$ of June & 29 & $24^{\text {th }}$ of June & 40 & $17^{\text {th }}$ of September & 125 \\
\hline 'Quisor' & $10^{\text {th }}$ of June & 26 & $19^{\text {th }}$ of June & 35 & $19^{\text {th }}$ of August & 96 \\
\hline 'Riana' & $10^{\text {th }}$ of June & 26 & $24^{\text {th }}$ of June & 40 & $21^{\text {th }}$ of August & 98 \\
\hline \multicolumn{7}{|c|}{ Second year } \\
\hline 'Balashi' & $11^{\text {th }}$ of July & 30 & $13^{\text {th }}$ of August & 63 & $6^{\text {th }}$ of October & 117 \\
\hline 'Bloktor' & $22^{\text {th }}$ of July & 41 & $12^{\text {th }}$ of August & 62 & $16^{\text {th }}$ of October & 127 \\
\hline 'Green Gem’ & $12^{\text {th }}$ of July & 31 & $13^{\text {th }}$ of August & 63 & $6^{\text {th }}$ of October & 117 \\
\hline 'Hurricane' & $17^{\text {th }}$ of July & 36 & $10^{\text {th }}$ of August & 60 & $16^{\text {th }}$ of October & 127 \\
\hline 'Quisor' & $14^{\text {th }}$ of July & 33 & $11^{\text {th }}$ of August & 61 & $9^{\text {th }}$ of October & 120 \\
\hline 'Riana' & $14^{\text {th }}$ of July & 33 & $11^{\text {th }}$ of August & 61 & $9^{\text {th }}$ of October & 120 \\
\hline
\end{tabular}

*d.a.t. $=$ days after transplantation

\section{Results}

\section{Antixenotic evaluation}

The assessments for both years yielded significant differences in thrips infestation between the studied varieties. For the antixenotic evaluation in the first year, the highest thrips density was found on the variety 'Green Gem. The varieties 'Quisor' and 'Hurricane' were colonised equally, but by fewer thrips than 'Green Gem. The varieties 'Blok- tor', 'Riana' and 'Balashi' that were categorised as resistant in previous studies (Fail et al., 2002, 2008; Fail, 2005, 2006), supported an even smaller thrips population in small cabbage heads (Fig. 1).

In the second year, the 'Green Gem' and 'Hurricane' varieties did not differ from each other in the number of invasive thrips, whereas significantly fewer adult thrips were observed on 'Quisor'. The resistant varieties were again less preferred by onion thrips than susceptible ones, 
although in the second year, there was no significant difference in the number of thrips between 'Bloktor' and one of the susceptible varieties, 'Quisor' (Fig. 1).

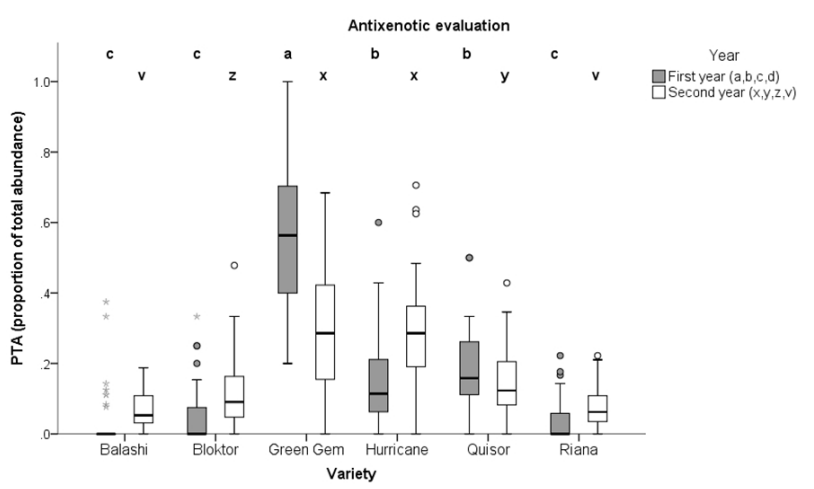

Fig. 1. Antixenotic evaluation at the beginning of head formation in the first and second years. Explanations: first year (a, b, $c)$, different letters represent significantly different values according to the applied statistical test $(p<0.05$, Mann-Whitney test). Second year ( $x, y, z, v)$, means with different letters are significantly different from each other according to the applied statistical test $(p<0.05$, Mann-Whitney test)

Statistics did not reveal a significant block effect in the first $(\mathrm{p}=0.13)$ or second year $(\mathrm{p}=0.4)$.

\section{Onion thrips damage assessment}

In the first year, 'Hurricane' suffered the highest total damaged leaf surface, followed by 'Green Gem' and 'Quisor'. The number of damaged leaves followed the same order (Fig. 2). Considerably less damage was observed on the resistant varieties ('Bloktor', 'Balashi' and 'Riana').

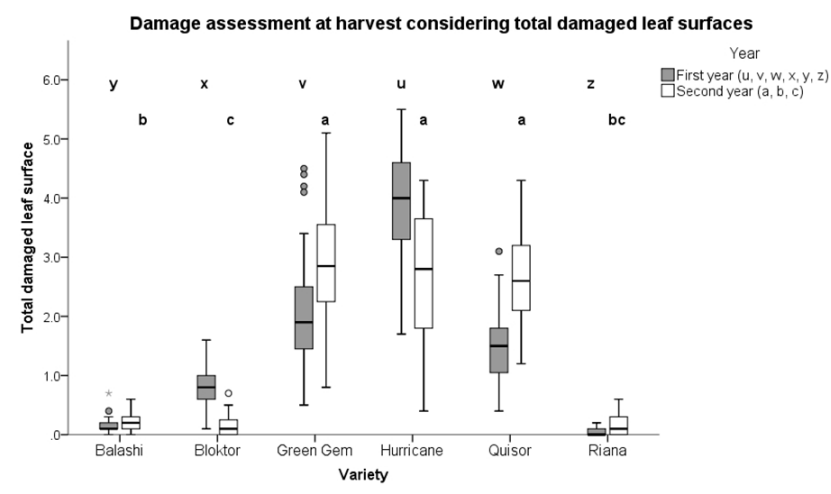

Fig. 2. Damage assessments at harvest considering total damaged leaf surfaces. Explanations: first year (u, v, w, x, y, z); second year $(a, b, c)$. Means with different letters are significantly different from each other according to the applied statistical test $(\mathrm{p}<$ 0.05, Mann-Whitney test)

We compared the number of colonising adult thrips in the previous evaluation with thrips damage assessed at harvest maturity in both years and highly positive correlations were observed (antixenotic evaluation and damage at harvest maturity in the first year was $0.541, \mathrm{p}<0.001$, and was 0.401 in the second year $\mathrm{p}<0.001$ by Spearman rank).

The order of the varieties according to total damaged leaf surface was slightly different in the second year; the three susceptible varieties showed no significant difference and a small but significant difference was found between 'Balashi' and 'Bloktor'. 'Riana' did not differ from either of the other two resistant varieties and the number of damaged leaves followed the same order as the total damage leaf surface (Fig. 3).

Similarly, no block effects on AR were detected in the first year (total damaged leaf surface $p=0.87$, number of damaged leaves $p=0.82$ ) or the second year (total damaged leaf surface $p=0.53$, number of damaged leaves $p=$ $0.15)$.

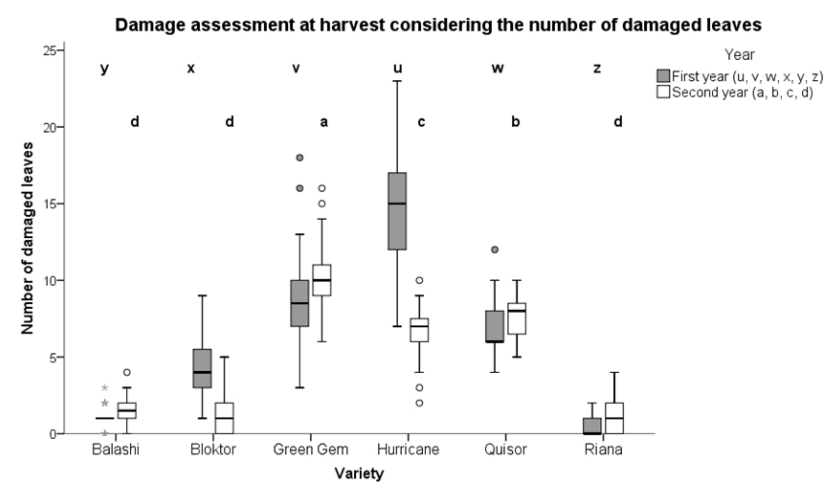

Fig. 3. Damage assessments at harvest considering the number of damaged leaves. Explanations: first year (u, v, w, x, y, z); second year $(a, b, c, d)$. Means with different letters are significantly different from each other according to the applied statistical test ( $p$ $<0.05$, Mann-Whitney test)

\section{Epidermal thickness evaluation}

In the first year, we measured the maximal epidermal thickness on the adaxial part of the leaves, and 'Riana' and 'Quisor' varieties showed significant differences compared to other varieties and also to each other. The thickness of the adaxial epidermis of 'Riana was approximately $18 \mu \mathrm{m}$, whereas that of 'Quisor' was less than $14 \mu \mathrm{m}$. Considering both epidermal sides, there was no significant difference in thickness between 'Green Gem' and 'Bloktor', whereas 'Riana' showed significant differences. The thickness of 'Hurricane' and 'Balashi' leaves was intermediate between that of the other two varieties. We also observed that the epidermal thickness on the abaxial and adaxial epidermis of 'Hurricane' (susceptible) and 'Balashi' (resistant) varieties did not differ significantly (Fig. 4).

In the second year, the three most susceptible varieties showed a greater thickness on the abaxial epidermis (Fig. 5). In the second year, maximum thickness on the adaxial part was measured for 'Hurricane', which was significantly different from the other varieties. 'Balashi' had the least thickness, which was significantly different from that of all the other varieties except 'Bloktor'. There were no signifi- 
448

cant differences in leaf thickness between 'Quisor', 'Green Gem', 'Riana' and 'Bloktor'. The epidermal thickness on the abaxial surface of 'Hurricane' leaves was significantly higher; and no differences between the other varieties was detected (Fig. 6).

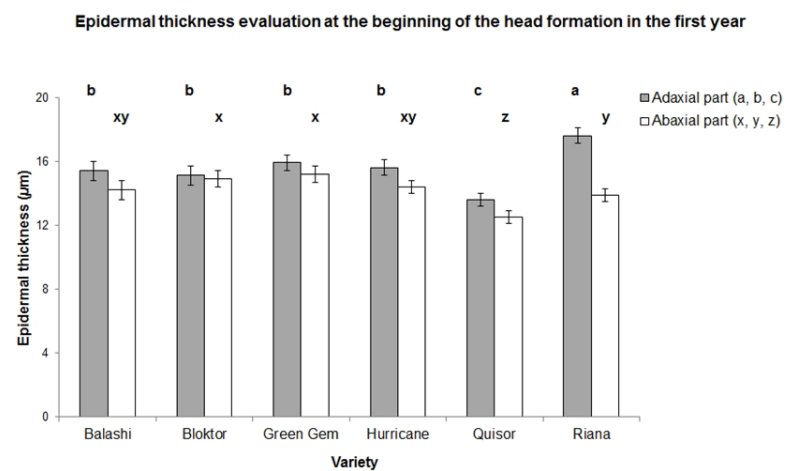

Fig. 4. Epidermal thickness evaluations at the beginning of the head formations in the first year. Explanations: adaxial part (a, $b, c)$, abaxial part $(x, y, z)$. Means with different letters are significantly different from each other according to the applied statistical test $(p<0.05$, Games-Howell test on adaxial part of epidermis, Tukey HSD test on abaxial part of epidermis). Error bars represent the $95 \%$ confidence interval of the mean

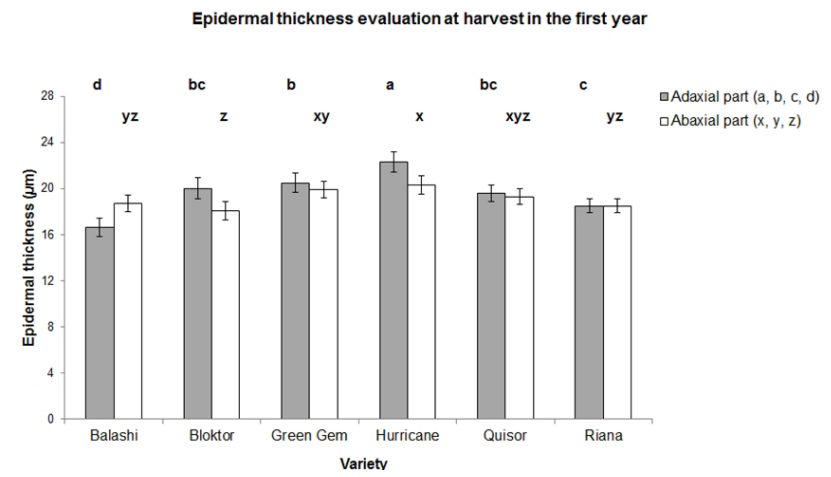

Fig. 5. Epidermal thickness evaluations at harvest in the first year. Means are shown in decreasing order. Explanations: adaxial part ( $a, b, c, d)$, abaxial part (x, y, z). Means with different letters are significantly different from each other according to the applied statistical test $(\mathrm{p}<0.05$, Tukey HSD test). Error bars represent the $95 \%$ confidence interval of the mean

No block effects of epidermal thickness were detected (first year cabbage head formation, adaxial part $p=0.35$, abaxial part $\mathrm{p}=0.1$, harvest adaxial part $\mathrm{p}=0.79$, abaxial part $\mathrm{p}=0.57$; second year cabbage head formation, adaxial part $\mathrm{p}=0.37$, abaxial part $\mathrm{p}=0.45$ ).

\section{Discussion and conclusions}

Considering AR, we can conclude that for both years, the density of onion thrips was always higher on suscep-

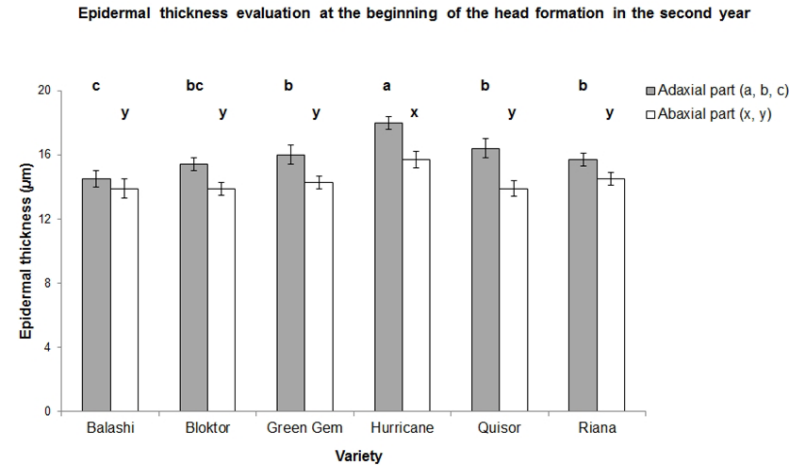

Fig. 6. Epidermal thickness evaluations at the beginning of the head formation in the second year. Means are shown in decreasing order. Explanations: adaxial part ( $\mathrm{a}, \mathrm{b}, \mathrm{c})$, abaxial part $(\mathrm{x}, \mathrm{y})$. Means with different letters are significantly different from each other according to the applied statistical test $(\mathrm{p}<0.05$, GamesHowell test on adaxial part of epidermis; Tukey HSD test on abaxial part of epidermis). Error bars represent the $95 \%$ confidence interval of the mean

tible ('Green Gem', 'Hurricane', 'Quisor') than on resistant ('Balashi', 'Bloktor', 'Riana') varieties. This difference clearly suggests that AR against thrips is present in white cabbage. Although highly positive correlations were observed between antixenotic evaluations and damage at harvest maturity, the correlation coefficients were less than one, suggesting that other mechanisms such as antibiosis and/or tolerance might also play an important role in the resistance of cabbage against onion thrips. Similar studies on adult western flower thrips (Frankliniella occidentalis Pergande, 1895) reported that during the feeding process, only the epidermal cells that showed a strong AR were damaged. Other plants lacking antixenotic resistance suffered severe damage to palisade parenchyma and to spongy parenchyma cells (Kumar et al., 1995).

The adaxial and abaxial epidermal thickness was examined in this study to assess whether it was correlated with resistance against onion thrips. Results indicate that susceptible white cabbage varieties often have a thicker epidermis than resistant ones; thus, epidermal thickness is not related to the resistance of a variety against thrips. During the growth of the cabbage head, there was a difference between the adaxial and abaxial epidermis for both susceptible and resistance varieties, with the exception of 'Bloktor' in the first year (Tab. 2). This is similar to findings in other studies, which have shown that the adaxial epidermis is much thicker than the abaxial epidermis (Painter, 1951). This difference appears to diminish in the second part of the growing season. For 'Balashi', we measured a greater abaxial epidermal thickness at harvest maturity (Tab. 2).

Based on our data, we conclude that resistance to onion thrips and epidermal thickness are not correlated for the six studied cabbage varieties. This lack of correlation might have a genetic basis that might influence the epidermal thickness. To date, no other data have related epidermal thickness to AR against onion thrips and our 
Tab. 2. Thickness of upper and lower epidermis $(\mu \mathrm{m})$ at the beginning of head formation in both years and at the harvest in first year. Means are presented in decreasing order

\begin{tabular}{|c|c|c|c|c|c|c|c|c|c|c|c|c|}
\hline \multirow[b]{3}{*}{ Variety } & \multicolumn{5}{|c|}{ First year } & \multicolumn{7}{|c|}{ Second year } \\
\hline & \multicolumn{5}{|c|}{ Beginning of head formation } & \multicolumn{3}{|c|}{ Harvest } & \multicolumn{4}{|c|}{ Beginning of head formation } \\
\hline & Side & Mean & a & Conf. $^{b}$ & Side & Mean & a & $\begin{array}{c}95 \% \\
\text { Conf. }^{\text {b }}\end{array}$ & Side & Mean & $\mathrm{a}$ & $\begin{array}{c}95 \% \\
\text { Conf. }\end{array}$ \\
\hline \multirow{2}{*}{ 'Balashi' } & adaxial & 15.4 & a & 0.6 & adaxial & 16.6 & a & 0.8 & adaxial & 14.5 & a & 0.5 \\
\hline & abaxial & 14.2 & b & 0.6 & abaxial & 18.7 & b & 0.7 & abaxial & 13.9 & $\mathrm{~b}$ & 0.6 \\
\hline \multirow{2}{*}{ 'Bloktor' } & adaxial & 15.1 & a & 0.6 & adaxial & 20.0 & a & 0.9 & adaxial & 15.4 & a & 0.4 \\
\hline & abaxial & 14.9 & a & 0.5 & abaxial & 18.1 & b & 0.8 & abaxial & 13.9 & $\mathrm{~b}$ & 0.4 \\
\hline \multirow{2}{*}{ 'Green Gem' } & adaxial & 15.9 & a & 0.5 & adaxial & 20.5 & a & 0.8 & adaxial & 16.0 & a & 0.6 \\
\hline & abaxial & 15.2 & b & 0.5 & abaxial & 19.9 & a & 0.7 & abaxial & 14.3 & $\mathrm{~b}$ & 0.4 \\
\hline \multirow{2}{*}{ 'Hurricane' } & adaxial & 15.6 & a & 0.5 & adaxial & 22.3 & a & 0.9 & adaxial & 18.0 & a & 0.4 \\
\hline & abaxial & 14.4 & b & 0.4 & abaxial & 20.3 & b & 0.8 & abaxial & 15.7 & b & 0.5 \\
\hline \multirow{2}{*}{ 'Quisor' } & adaxial & 13.6 & a & 0.4 & adaxial & 19.6 & a & 0.7 & adaxial & 16.4 & a & 0.6 \\
\hline & abaxial & 12.5 & b & 0.4 & abaxial & 19.3 & a & 0.7 & abaxial & 13.9 & b & 0.5 \\
\hline \multirow{2}{*}{ 'Riana' } & adaxial & 17.6 & a & 0.5 & adaxial & 18.5 & a & 0.6 & adaxial & 15.7 & a & 0.4 \\
\hline & abaxial & 13.9 & b & 0.4 & abaxial & 18.5 & a & 0.6 & abaxial & 14.5 & b & 0.4 \\
\hline
\end{tabular}

a Significance: Means with different letters are significantly different from each other according to the applied statistical test ( $\mathrm{p} \leq 0.05$, $\mathrm{t}$-test or Welch $\mathrm{t}$-test) b $95 \%$-confidence intervals of means

data represent the first evidence that no relationship exists between epidermal thickness of white cabbage leaves and AR to onion thrips. Further research is therefore needed to identify the physiological, morphological, and genetic basis of white cabbage resistance to onion thrips.

\section{Acknowledgements}

We are grateful to all employees and students of the Entomology Department of the Corvinus University Budapest for their valuable contribution to this study. This study was financially supported by the Balassi Institute, Hungarian Scholarship Board Office and the Institute for Ethnic and National Minority Studies of the Hungarian Academy of Sciences. The Bakker Brothers, Bejo Zaden B.V., Daehnfeldt A/S and Syngenta Seeds Inc. are acknowledged for providing seeds for this study.

\section{References}

Abdel-Gawaad AA, El-Gayar FH, Soliman AS, Zaghlool OA (1973). Studies on Thrips tabaci Lindeman X. Mechanism of resistance to Thrips tabaci L. in cotton varietes. J Appl Entomol 73:251-255.

Ananthakrishnan TN (1955). Host preferences in Retithrips syriacus (Mayet). Agra Univ J Res 4:284-288.

Chisholm IF, Lewis T (1984). A new look at thrips (Thysanoptera) mouthparts, their action and effects of feeding on plant tissue. Bull Entomol Res 74:663-675.

Fail J (2005). A dohánytripsz kártétele fejes káposztán. PhD thesis. University Corvinus of Budapest.

Fail J (2006). Fejeskáposzta-fajták ellenállósága a dohánytripsszel szemben. Zöldségtermesztés 37:21-27.

Fail J, Pénzes B, Szani Sz, Hudák K (2002). Dohánytripsz-ellenálló fejes káposzta fajták. Növényvédelem 38:561-570.
Fail J, Zana J, Pénzes B (2008). The role of plant characteristics in the resistance of white cabbage to onion thrips: Preliminary results. Acta Phytopathol Entomol Hung 43:267-275.

Højsgaard S, Halekoh U, Yan J (2006). The R Package geepack for Generalized Estimating Equations. Journal of Statistical Software 15:1-11.

Horton JR (1918). The citrus thrips. Bulletin of the US Department of Agriculture 616, 413.

Lintner JA (1892). A thrips attack on cabbage. Country Gentleman $57,809$.

Naik SI, Reddy DNR, Sannappa B (2000). Relation between Pseododendrothrips mori population and leaf characters in mulberry varieties. Karnataka J Agric Sci 13:60-63.

Painter RH (1951). Resistance to Thrips, in: Insect Resistance in Crop Plants. MacMillan, pp. 297-302.

R Core Team (2012). R: A Language and Environment for Statistical Computing. R Foundation for Statistical Computing, Vienna, Austria.

Sirrine FA, Lowe VH (1894). Insects affecting late cabbage. New York Agricultural Experiment Station Bulletin 83:657-684.

Wardle RA, Simpson R (1927). The biology of Thysanoptera with reference to the cotton plant. Ann Appl Biol 14:513528.

Yan J, Højsgaard S (2012). Generalized Estimating Equation Package. R-News.

Zatykó F (2004). Fejes káposzta, in: Hodossi, S., Kovács, A., Terbe, I. (Eds.), Zöldségtermesztés Szabadföldön. Mezőgazda Kiadó Budapest, pp. 303-309.

Zeier P, Wright MG (1995). Thrips resistance in Gladiolus spp.: potential for IPM and breeding. NATO ASI series. Series A, Life sciences 276:411-416. 